\title{
Spatialization of Granulometric and Chemical Characteristics in Irrigated Hydromorphic Soil
}

\author{
Murilo Alceu de Águas \\ Federal Institute of Education, Science and Technology Goiano - Campus Ceres, Brazil \\ E-mail: murilo_aguas@hotmail.com
}

Joaquim José Frazão

Dept. of Agricultural Sciences, Maranhão State University, Brazil

E-mail: jj.ss.brs@gmail.com

\section{Leonardo Mariano do Nascimento}

Federal Institute of Education, Science and Technology Goiano - Campus Ceres, Brazil E-mail: agroleonardonascimento@gmail.com

\section{João Paulo Souza Carneiro}

Federal Institute of Education, Science and Technology Goiano - Campus Ceres, Brazil E-mail: joaopaulo_agronomia14@hotmail.com

\section{Ariel Muncio Compagnon}

Federal Institute of Education, Science and Technology Goiano - Campus Ceres, Brazil E-mail: ariel.compagnon@ifgoiano.edu.br

Ana Paula Santos Oliveira

Federal Institute of Education, Science and Technology Goiano - Campus Ceres, Brazil E-mail: anapaula.oliveira@ifgoiano.edu.br 
Valter dos Santos Marques

Federal Institute of Education, Science and Technology Goiano - Campus Ceres, Brazil

E-mail: valter.marques@ifgoiano.edu.br

\author{
Vagner Alves da Silva \\ Agency for Technical Assistance, Rural Extension and Agricultural Research of Goiás \\ (EMATER), Brazil \\ E-mail: vasilva09@gmail.com
}

Roriz Luciano Machado (Corresponding author)

Federal Institute of Education, Science and Technology Goiano - Campus Ceres, Road GO-154, Km 03, 76300-000, Ceres, GO, Brazil

E-mail: roriz.machado@ifgoiano.edu.br

Received: May 14, 2021 Accepted: June 14, 2021 Published: June 24, 2021

doi:10.5296/jas.v9i3.18802

URL: https://doi.org/10.5296/jas.v9i3.18802

\begin{abstract}
Lowlands represent a significant portion of agricultural areas in the world. Thus, understanding the spatial variability of the chemical and granulometric characteristics of hydromorphic soils can contribute to improving soil management and fertility. The objective of this work was to characterize spatial dependence, spatialized chemical attributes, granulometry, and the ideal number of samples in irrigated hydromorphic soil. Soil sampling was conducted in a grid of $10 \times 10 \mathrm{~m}$, in the layers of $0-0.1$ and $0.1-0.2 \mathrm{~m}$, totalling 432 composite samples. The evaluated attributes are as follows: $\mathrm{pH}$ in water, $\mathrm{H}+\mathrm{Al}, \mathrm{SOM}, \mathrm{Ca}$, $\mathrm{Mg}, \mathrm{Al}, \mathrm{P}, \mathrm{K}, \mathrm{CTC}, \mathrm{V} \%, \mathrm{Cu}, \mathrm{Fe}, \mathrm{Zn}, \mathrm{Mn}$, clay, silt, and sand. The texture of the area was classified as loamy-sandy and free in the $0-0.1$ and $0.1-0.2 \mathrm{~m}$ layers, respectively. The coefficient of variation of the attributes ranged from $2.71 \%(0-0.1 \mathrm{~m})$ to $149.07 \%(0.1-0.2 \mathrm{~m})$. All the attributes studied exhibited moderate to strong spatial dependence. The sample grid with a sampling interval of $20 \mathrm{~m}$ referring to the $0-0.1 \mathrm{~m}$ layer proved to be adequate. The ideal number of simple samples per composite is 19 for granulometry and macronutrients, and 28 for the micronutrients in the $0-0.1 \mathrm{~m}$ layer.
\end{abstract}

Keywords: soil fertility, flood plain, spatial variability, soil sampling

\title{
1. Introduction
}


Irrigation in lowlands or floodplains is important for agricultural food production. Geotechnology can be utilized to characterize soil fertility in irrigated landscapes, with the aim of optimizing management and improving sustainability.

Globally, there is an estimated 93 million ha of rice cultivated in irrigated lowlands, corresponding to $75 \%$ of the total rice production (GRiSP, 2013). In Asia, this ecosystem is responsible for about 45 million ha (Haefele et al., 2014). In Brazil, Rio Grande do Sul has 5.4 million ha of lowland, and rice is cultivated in an irrigated portion (1.1 million ha) of this area (Cassol, 2017); this makes the state of Rio Grande do Sul the largest producer of rice (Andres et al., 2012). Tocantins (TO) has more than 500,000 ha of floodplain area, 9\% of which is used for rice cultivation during the rainy season, and is mostly concentrated in the municipalities of Cristalândia, Dueré, Formoso do Araguaia, Lagoa da Confusão, and Pium (Kischel et al., 2011). In Goiás (GO), cultivation in lowlands or, more appropriately, in flood plains is predominant in the regions of Flores de Goiás, Formoso, and Luiz Alves, where there are public incentives for the implementation of the projects.

Generally, lowlands or floodplains have lower-fertility soil compared to those of other irrigated environments (Haefele et al., 2014). In these environments, the mobility of mineral fertilizers (Aidar et al., 2002), nutrient dynamics, and the decomposition of organic matter are altered. Much of the fertilizer recommendation is made based on the requirements of upland environments. In addition, the recommendations generally disregard the particularities of flooded lands, such as spatial variability of the soil due to systematization, variability in water availability, topographic interference (Haefele et al., 2016), and nutrient dynamics under soil redox conditions.

The heterogeneity in the physical and chemical properties of the soil significantly influences the performance of the crops, both quantitatively and qualitatively, and precision agriculture can contribute to reducing the environmental impacts on agricultural productivity (Benedetto et al., 2012). The most accurate estimates of the spatial variability of the soil properties can be obtained by observing the elements of autocorrelation and random variation (Montanari et al., 2012; Rosemary et al., 2017) allowing for the planning of appropriate sampling schemes (Kerry et al., 2010) for fertility diagnosis. Kriging is one of the most used methods in geostatistics (Uyan, 2016) for data interpolation in non-sampled points (Barik et al., 2014), which allows the mapping of the attributes of interest. In this paper, we present the results of a study on the physical and chemical properties of soil, using soil maps, in homogeneous units, which contributes to irrigation management (Jiménez-Aguirrea et al., 2018) and sustainable management of agricultural areas (Bogunovic et al., 2017). Therefore, it is possible to use fertilizers at a variable rate (Najafian et al., 2012) to increase fertilization efficiency and crop productivity (Tesfahunegn et al., 2011).

To conserve resources, most consultancies related to precision agriculture (AP) do not adopt previous data on the spatial variability of nutrients and the definition of the ideal number of samples. Thus, the development of maps for farmers trying to apply fertilizers at variable rates is often based on criteria obtained off-site, which interferes with the accuracy of the mapping. 
In areas of hydromorphic soils, irrigated by surface and sub-irrigation (groundwater) methods in the state of Goiás, Brazil few studies have been conducted with the objective of understanding the spatial variability and mapping of chemical and physical soil attributes. Consequently, the objective of this work was to characterize the spatial dependence, the sampling grid, spatialized chemical attributes, granulometry, and the ideal number of hydromorphic soil samples from an area irrigated by surface and sub-irrigation methods at the Luís Alves Irrigation Project site.

\section{Method}

This study was conducted at the Luís Alves do Araguaia Irrigation Project (PILAA) site, in Luiz Alves (GO), the São Miguel do Araguaia district - GO, Brazil (Figure 1). The total area of the first stage of the project was 1,843.92 ha (GOIÁS, 2020) and is located in Zone 22L of the Universal Transverse System of Mercator (UTM) with geographic coordinates $547525,5680 \mathrm{~m} \mathrm{(E)}$ and $8537244,9750 \mathrm{~m}(\mathrm{~S})$. The climate of the region falls in the Aw Tropical Climate of Savana - hot and rainy summer and mild and dry winter, according to the Köppen climate classification (Köppen, 1931). The study area is located in the Araguaia river floodplain, which is irrigated by surface water method during the dry season and by sub-irrigation method with variable groundwater during the rainy season (October to April).
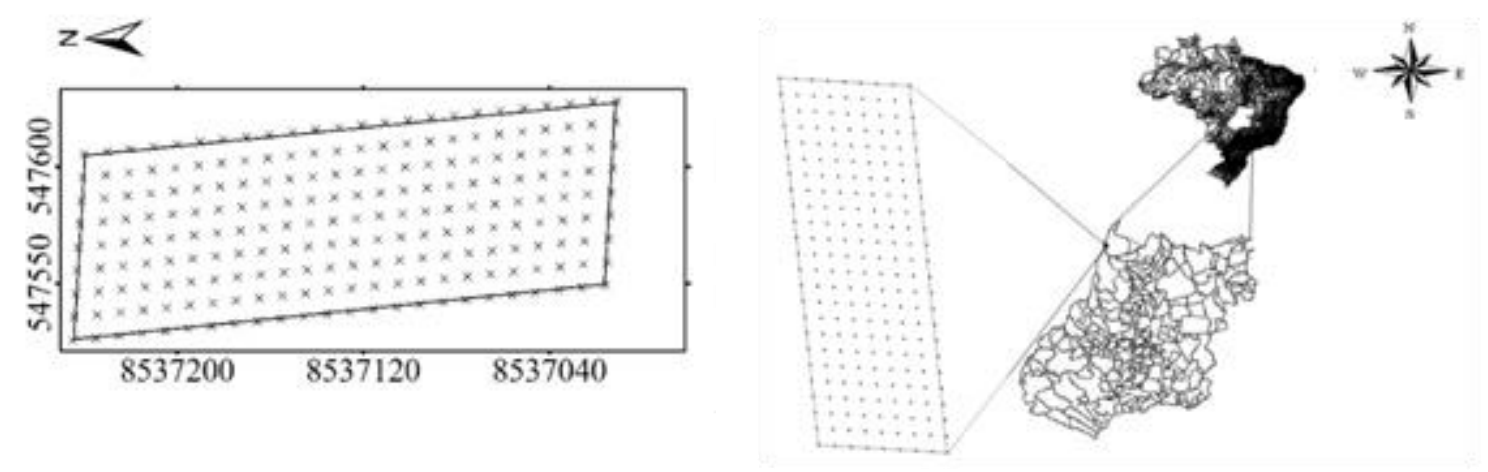

Figure 1. Location of the study area

The area has been used by farmers since the year 2000. Rice crops are cultivated in the wet/rainy season (October to March) and other crops during the dry season (April to September), such as sorghum, watermelon, Kabutiá pumpkin, melon, cowpea, industrial tomato, soybean, and corn (GOIÁS, 2020), with the latter two predominating. Usually, after the rice harvest, the straw is burnt based on the argument that it hinders the germination of seeds; subsequently, the conventional preparation of the soil by grating is carried out, aiming at planting rice, corn, or other crops.

The experiment was conducted on an area with the dimensions of 230 x $80 \mathrm{~m}$ (1.84 ha), where the soil sampling was conducted in October 2016 at depths ranges of $0.0-0.1 \mathrm{~m}$ and 0.1-0.2 m. The sample mesh was $10 \times 10 \mathrm{~m}$, according to the literature (Parfitt et al., 2009; Bitencourt et al., 2016), totaling 432 composite samples. Each composite sample was sourced from three simple samples collected during the interweaving of the soybean crop with the aid 
of a Dutch type auger.

A total of 216 points were georeferenced and a file was created with the coordinates in the UTM of each point in the area, associated with the physical and chemical attributes under study. The soil morphology and classification of the studied area were determined according to the Brazilian System of Soil Classification (SBCS) (Santos et al., 2018), being a Plintossolo Háplico (Plinthosols).

To evaluate and determine the correlation between the attributes, a particle size analysis was performed by the pipette method on the samples collected, according to Donagema et al. (2011). The $\mathrm{pH}\left(\mathrm{H}_{2} \mathrm{O}\right), \mathrm{H}+\mathrm{Al}$, soil organic matter (SOM), Ca, $\mathrm{Mg}, \mathrm{Al}, \mathrm{P}, \mathrm{K}, \mathrm{CTC}, \mathrm{V}, \mathrm{Cu}, \mathrm{Fe}$, $\mathrm{Zn}$, and Mn attributes were chemically analyzed.

The soil organic matter was extracted by oxidation with sodium dichromate and determined by colorimetry; P was extracted by Mehlich I and determined by colorimetry. The other nutrients were extracted by $\mathrm{KCl}$ and determined by atomic absorption spectrometry, except Al, which was determined by titration with sodium hydroxide (Donagema et al., 2011).

Based on the results of the analysis, descriptive statistics were applied as mean, median, minimum, maximum, coefficient of variation (CV), asymmetry, kurtosis, standard deviation, and normality test - Kolmogorov-Smirnov (Silva \& Azevedo, 2016). To evaluate the spatial variability and the mapping of the physical and chemical attributes of the studied soil, the spatial dependence of the data was evaluated using the GS+ 7.0 software (Robertson, 1998) using semivariance (Equation 1).

$$
\gamma(h)=\frac{1}{2 \mathrm{~N}(h)} \sum_{i=1}^{N(h)}[Z(x i)-Z(x i+h)]^{2}
$$

where (h) is the estimated semivariance at distance $h ; N(h)$, the number of pairs of values $[Z$ (xi), $\mathrm{Z}(\mathrm{xi}+\mathrm{h})$ ] separated by vector $\mathrm{h}$; Xi, the spatial position of variable $\mathrm{Z}$, and $\mathrm{Z}$ (xi), the value of property $\mathrm{Z}$ in location $\mathrm{xi}$ in space.

For selecting the most adequate semivariogram, the highest coefficient of determination $\left(\mathrm{R}_{2}\right)$ and the smallest square sum of the residuals ( $\mathrm{SQR}$ ) were used as criteria. After adjusting the semivariograms, the data were cross-validated using the GS+7.0 software (Robertson, 1998). For the attributes that exhibited spatial dependence, kriging interpolation was performed using the same software.

The kriging results of the physical and chemical analysis data were used in the preparation of iso-occurrence maps, using the ArcGIS software (Esri, 2014), having the respective classes of interpretation of the nutrient level as the class interval criteria, according to Sousa \& Lobato (2004). To evaluate the degree of spatial dependence, the criterion, suggested by Cambardella et al. (1994) and modified by Zimback (2001), called the spatial dependency index (SDI), was employed.

\section{Results and Discussion}




\subsection{Descriptive Statistics}

Analyzing the clay content (Table 1), the soil texture of the study area was classified as clay-sandy-loam and free for the layers of $0.0-0.1 \mathrm{~m}$ and $0.1-0.2 \mathrm{~m}$, respectively, based on the textural triangle (Santos et al., 2015a).

The values of the attributes, $\mathrm{pH}\left(\mathrm{H}_{2} \mathrm{O}\right), \mathrm{SOM}, \mathrm{Ca}, \mathrm{Mg}, \mathrm{P}$, and $\mathrm{K}$ in the depth range of $0.0-0.1$ $\mathrm{m}$, and those of the attributes, SOM, Ca, Mg, CTC, V\%, and Fe in the depth range of 0.1-0.2 $\mathrm{m}$ were close or equal (mean and median), indicating a normal distribution, which can be confirmed by the Kolmogorov-Smirnov test (Table 1). Additionally, the median of most of the soil attributes under study was lower than the mean (Table 1), indicating that the magnitude of the abnormal data in the sample value was not as high.

\subsection{Observing the Variability of the Data for the Soil Properties Analyzed by the Coefficient of Variation (\% CV)}

The results ranged from $3.3 \%(\mathrm{pH}, 0.0-0.1 \mathrm{~m})$ to $149.07 \%(\mathrm{Cu}, 0.1-0.2 \mathrm{~m})$ (Table 1). It was verified that in the depth range of $0.0-0.1 \mathrm{~m}$, the attributes, $\mathrm{pH}\left(\mathrm{H}_{2} \mathrm{O}\right), \mathrm{V} \%$, and $\mathrm{Fe}$, varied slightly and the other attributes exhibited average variation, according to Warrick \& Nielsen (1980). This low variability, particularly for the $\mathrm{pH}\left(\mathrm{H}_{2} \mathrm{O}\right)$ attribute, can occur, according to Reza et al. (2017), because the values of this attribute are presented in a log scale of the concentration of protons in the soil solution. Polo et al. (2010), Reza et al. (2016), and Shukla et al. (2016), in their studies, verified the low $\mathrm{CV}$ of the $\mathrm{pH}\left(\mathrm{H}_{2} \mathrm{O}\right)$, when compared with those of other soil properties, thereby corroborating this work.

Table 1. Descriptive statistics for the attributes analyzed in areas using surface irrigation and subirrigation methods at Luiz Alves - GO

Attribute Mean Median Minimum Maximum SD CV Asymmetry Kurtose ND $-0.1 \mathrm{~m}$

$\begin{array}{cccccccccc}\text { Clay }^{(1)} & 270.7 & 247.8 & 98.7 & 463.8 & 75.5 & 27.9 & 0.1 & -1.1 & 0.1^{\mathrm{A}} \\ \mathrm{Silt}^{(1)} & 230.9 & 220.9 & 77.8 & 390.6 & 57.2 & 24.8 & 0.8 & 0.5 & 0.1^{\mathrm{A}} \\ \mathrm{Sand}^{(1)} & 498.4 & 451.1 & 365.2 & 785.4 & 95.4 & 19.1 & 0.6 & -0.9 & 0.2^{\mathrm{A}} \\ \mathrm{pH}\left(\mathrm{H}_{2} \mathrm{O}\right) & 5.3 & 5.3 & 4.8 & 6.0 & 0.2 & 3.3 & 0.2 & 0.6 & 0.1^{\mathrm{N}} \\ \mathrm{SOM}^{(1)} & 20.2 & 20.2 & 14.0 & 29.2 & 2.5 & 12.4 & 0.3 & 0.4 & 0.0^{\mathrm{N}} \\ \mathrm{Ca}^{(2)} & 2.3 & 2.2 & 1.2 & 3.5 & 0.4 & 19.9 & 0.2 & -0.4 & 2.5^{\mathrm{N}} \\ \mathrm{Mg}^{(2)} & 0.9 & 0.9 & 0.3 & 1.6 & 0.3 & 30.1 & 0.4 & -0.1 & 0.1^{\mathrm{N}}\end{array}$




\begin{tabular}{|c|c|c|c|c|c|c|c|c|c|}
\hline $\mathrm{Al}^{(2)}$ & 0.5 & 0.5 & 0.1 & 1.2 & 0.2 & 43.9 & 1.0 & 0.5 & $0.1^{\mathrm{A}}$ \\
\hline $\mathrm{H}+\mathrm{Al}^{(2)}$ & 2.6 & 2.5 & 1.3 & 3.8 & 0.5 & 18.4 & 0.3 & -0.3 & $0.1^{\mathrm{A}}$ \\
\hline $\mathrm{P}^{(3)}$ & 109.9 & 101.0 & 12.2 & 202.0 & 31.2 & 28.4 & 0.5 & 1.1 & $0.1^{\mathrm{A}}$ \\
\hline $\mathrm{K}^{(3)}$ & 195.3 & 193.8 & 85.5 & 292.3 & 42.5 & 21.8 & 0.0 & -0.1 & $0.1^{\mathrm{N}}$ \\
\hline $\mathrm{CTC}^{(2)}$ & 6.3 & 6.3 & 4.3 & 8.7 & 0.9 & 13.7 & -0.0 & -0.1 & $0.1^{\mathrm{A}}$ \\
\hline $\mathrm{V}^{(4)}$ & 57.7 & 58.3 & 40.1 & 79.6 & 6.8 & 11.9 & -0.1 & -0.2 & $0.1^{\mathrm{A}}$ \\
\hline $\mathrm{Cu}^{(3)}$ & 1.6 & 1.7 & 0.8 & 2.9 & 0.4 & 25.4 & -0.1 & -0.6 & $0.1^{\mathrm{A}}$ \\
\hline $\mathrm{Fe}^{(3)}$ & 336.4 & 345.2 & 265.0 & 369.7 & 22.9 & 6.8 & -0.8 & -0.2 & $0.2^{\mathrm{A}}$ \\
\hline $\mathrm{Zn}^{(3)}$ & 2.7 & 2.5 & 0.8 & 10.5 & 1.3 & 47.0 & 2.2 & 9.3 & $0.1^{\mathrm{A}}$ \\
\hline $\mathrm{Mn}^{(3)}$ & 17.5 & 17.1 & 5.0 & 43.5 & 9.4 & 53.9 & 0.6 & -0.5 & $0.1^{\mathrm{A}}$ \\
\hline Clay & 214.2 & 207.5 & 97.4 & 418.2 & 77.5 & 28.7 & 0.4 & 0.0 & $0.1^{\mathrm{A}}$ \\
\hline Silt & 291.5 & 306.8 & 111.1 & 427.6 & 61.6 & 26.6 & -0.6 & -0.7 & $0.1^{\mathrm{A}}$ \\
\hline Sand & 494.3 & 445.0 & 333.2 & 773.6 & 116.2 & 23.5 & 1.0 & -0.5 & $0.2^{\mathrm{A}}$ \\
\hline $\mathrm{pH}\left(\mathrm{H}_{2} \mathrm{O}\right)$ & 5.4 & 5.1 & 4.4 & 7.1 & 0.7 & 12.2 & 0.7 & -0.7 & $0.2^{\mathrm{A}}$ \\
\hline SOM & 10.2 & 10.2 & 4.7 & 17.5 & 2.6 & 25.4 & 0.0 & -0.6 & $0.1^{\mathrm{N}}$ \\
\hline $\mathrm{Ca}$ & 1.6 & 1.6 & 0.6 & 2.6 & 0.4 & 25.9 & 0.2 & -0.4 & $0.0^{\mathrm{N}}$ \\
\hline $\mathrm{Mg}$ & 0.8 & 0.8 & 0.2 & 1.6 & 0.2 & 30.5 & 0.4 & 0.1 & $0.0^{\mathrm{N}}$ \\
\hline $\mathrm{Al}$ & 0.9 & 0.8 & 0.1 & 2.7 & 0.7 & 79.4 & 0.5 & -0.9 & $0.1^{\mathrm{A}}$ \\
\hline $\mathrm{H}+\mathrm{Al}$ & 4.3 & 4.2 & 1.3 & 8.8 & 1.9 & 44.7 & 0.2 & -1.1 & $0.1^{\mathrm{A}}$ \\
\hline $\mathrm{P}$ & 31.3 & 27.5 & 3.1 & 119.0 & 20.6 & 65.8 & 1.3 & 2.4 & $0.1^{\mathrm{A}}$ \\
\hline
\end{tabular}




\begin{tabular}{cccccccccc}
$\mathrm{K}$ & 33.8 & 28.2 & 4.2 & 242.5 & 25.8 & 76.4 & 3.7 & 22.0 & $0.2^{\mathrm{A}}$ \\
$\mathrm{CTC}$ & 6.7 & 7.0 & 3.5 & 11.2 & 1.8 & 26.8 & 0.0 & -1.1 & $0.1^{\mathrm{N}}$ \\
$\mathrm{V}$ & 39.2 & 37.9 & 11.5 & 73.1 & 14.4 & 36.8 & 0.3 & -0.9 & $0.1^{\mathrm{N}}$ \\
$\mathrm{Cu}$ & 0.2 & 0.0 & 0.0 & 1.3 & 0.3 & 149.1 & 1.6 & 2.6 & $0.3^{\mathrm{A}}$ \\
$\mathrm{Fe}$ & 461.4 & 462.6 & 233.5 & 630.3 & 82.4 & 17.9 & -0.3 & -0.3 & $0.0^{\mathrm{N}}$ \\
$\mathrm{Zn}$ & 1.3 & 1.0 & 0.0 & 11.4 & 1.3 & 106.5 & 4.4 & 25.7 & $0.2^{\mathrm{A}}$ \\
$\mathrm{Mn}$ & 7.0 & 6.6 & 1.3 & 22.0 & 3.7 & 53.0 & 1.4 & 2.8 & $0.1^{\mathrm{A}}$ \\
\hline
\end{tabular}

SD - Standard deviation; CV - Coefficient of variation; ND - Normality of the data by the Kolmogorov-Smirnov test ( $\mathrm{p} \leq 0.05)$; A: Asymmetric distribution; N: Normal distribution; ${ }^{(1)} \mathrm{g} \mathrm{kg}^{-1}$; ${ }^{(2)} \mathrm{Cmol}_{\mathrm{c}} \mathrm{dm}^{-3}$; ${ }^{(3)} \mathrm{mg} \mathrm{dm}^{-3}$; ${ }^{(4)} \%$; $\mathrm{SOM}$ - soil organic matter; $\mathrm{Ca}$ - calcium; Mg-magnesium; $\mathrm{Al}$ - aluminum; $\mathrm{H}+\mathrm{Al}$ - potential acidity; $\mathrm{P}$ - phosphorus; K-potassium; CTC - cation exchange capacity; V - base saturation; $\mathrm{Cu}$ - copper; $\mathrm{Fe}$ - iron; $\mathrm{Zn}$ - zinc; $\mathrm{Mn}$ manganese.

From the $0.1-0.2 \mathrm{~m}$ depth range analysis, all the attributes showed average variation, except for the attributes, $\mathrm{Al}, \mathrm{P}, \mathrm{K}, \mathrm{Cu}$, and $\mathrm{Zn}$, which varied significantly. In most of the samples, the $\mathrm{Cu}$ and $\mathrm{Zn}$ nutrient levels were not detectable. This relatively high variation of the $\mathrm{Cu}$ level may be related, among other factors, to the soil granulometry. Marques Júnior et al. (2014), studying Planosols in a depth range of $0.0-0.2 \mathrm{~m}$, found $\mathrm{CV}$ values close to those in the present study for $\mathrm{Ca}, \mathrm{Mg}, \mathrm{H}+\mathrm{Al}$, and clay.

For nutrients $\mathrm{P}$ and $\mathrm{K}$, soil fertility management (correction and fertilization) may have contributed to the variability of the data, considering the history of application in lines or the haul with sources and variable doses throughout the years of cultivation. In addition, the unevenness of the irrigation during the dry season, due to irregularities in the wetting of the area, can also influence the dynamics of these nutrients and, consequently, the results obtained.

\subsection{Analysis of the Adjusted Semivariograms}

The soil granulometric analysis indicated the spatial dependence for all attributes (clay, silt, and sand). For the attributes in clay and sandy soils, the Gaussian model was the best fit for the depth range of $0.0-0.1 \mathrm{~m}$. The exponential and spherical models presented better adjustment for clay and sand in the $0.1-0.2 \mathrm{~m}$ layer and in silt depth ranges of $0.0-0.1$ and $0.1-0.2 \mathrm{~m}$, respectively (Table 2 ).

Bitencourt et al. (2016), studying lowland soils in a depth range of $0.0-0.2 \mathrm{~m}$ before soil leveling, observed that the Gaussian model presented the best fit for clay and sand, in 
agreement with the present study. The achieved value for soil granulation ranged from $94.7 \mathrm{~m}$ for clay in depths of $0.0-0.1 \mathrm{~m}$, to $243.6 \mathrm{~m}$ for silt in the $0.0-0.1 \mathrm{~m}$ layer. The highest range values for granulometry were always associated with a depth of $0.1-0.2 \mathrm{~m}$, except for the silt attribute (Table 2).

For the chemical attributes, spatial dependence was also observed, indicating that the study area was not homogeneous. Normally, for each crop the soil receives fertilizers (that can vary in types, dosages, times and forms of application), and this can be an additional cause of spatial variability in chemical attributes (Canton et al., 2021). The research data were mostly adjustable to the Gaussian model (47\% of attributes), followed by exponential (29\%) and spherical (23\%) models, considering the two layers (0.0-0.2 m). Marques Júnior et al. (2014) studied Planosol at depths of $0.0-0.2 \mathrm{~m}$ and found that most of the soil properties were better fitted to the spherical model than to other models.

Table 2. Adjustment parameters of experimental semivariograms for soil attributes in areas using surface irrigation and subirrigation methods at Luiz Alves - GO

\begin{tabular}{|c|c|c|c|c|c|c|c|c|c|}
\hline Attribute & Depth (m) & MDL & $\mathrm{C}_{0}$ & $\mathrm{C}_{0}+\mathrm{C}$ & $\mathrm{A}_{0}$ & $\mathrm{R}^{2}$ & SQR & SDI & GDE \\
\hline \multirow{3}{*}{ Clay } & $0-0.1$ & GAU & 2110.00 & 9013.00 & 94.70 & 0.97 & $5.02 \mathrm{E}^{+06}$ & 77 & Strong \\
\hline & & & & & & & & & \\
\hline & $0.1-0.2$ & EXP & 1350.00 & 7168.00 & 158.90 & 0.89 & $4.33 \mathrm{E}^{+06}$ & 81 & Strong \\
\hline \multirow{2}{*}{ Silt } & $0-0.1$ & EXP & 1870.00 & 6552.00 & 243.60 & 0.94 & $9.00 \mathrm{E}^{+05}$ & 71 & Moderate \\
\hline & $01-02$ & ESF & 7000 & 940900 & 17380 & 097 & $539 \mathrm{E}^{+06}$ & 99 & Strono \\
\hline \multirow{3}{*}{ Sand } & $0-0.1$ & GAU & 460.00 & 23930.00 & 132.60 & 0.99 & $5.19 \mathrm{E}^{+06}$ & 98 & Strong \\
\hline & & & & & & & & & \\
\hline & $0.1-0.2$ & ESF & 860.00 & 22760.00 & 201.40 & 0.95 & $5.20 \mathrm{E}^{+07}$ & 96 & Strong \\
\hline \multirow{3}{*}{$\mathrm{pH}\left(\mathrm{H}_{2} \mathrm{O}\right)$} & $0-0.1$ & EXP & 0.01 & 0.03 & 20.90 & 0.62 & $3.20 \mathrm{E}^{-04}$ & 86 & Strong \\
\hline & & & & & & & & & \\
\hline & $0.1-0.2$ & GAU & 0.04 & 0.91 & 110.00 & 0.96 & $8.92 \mathrm{E}^{-02}$ & 96 & Strong \\
\hline \multirow{2}{*}{ SOM } & $0-0.1$ & GAU & 2.87 & 25.73 & 246.70 & 0.99 & $6.39 \mathrm{E}^{+00}$ & 89 & Strong \\
\hline & $0.1-0.2$ & GAU & 2.45 & 14.72 & 140.10 & 0.99 & $3.96 \mathrm{E}^{+00}$ & 83 & Strong \\
\hline \multirow{3}{*}{$\mathrm{Ca}$} & $0-0.1$ & ESF & 0.09 & 0.52 & 510.90 & 0.91 & $1.55 \mathrm{E}^{-02}$ & 83 & Strong \\
\hline & & & & & & & & & \\
\hline & $0.1-0.2$ & EXP & 0.01 & 0.16 & 8.70 & 0.29 & $7.06 \mathrm{E}^{-03}$ & 91 & Strong \\
\hline $\mathrm{Mg}$ & $0-0.1$ & GAU & 0.04 & 0.61 & 497.40 & 0.89 & $3.13 \mathrm{E}^{-03}$ & 93 & Strong \\
\hline
\end{tabular}




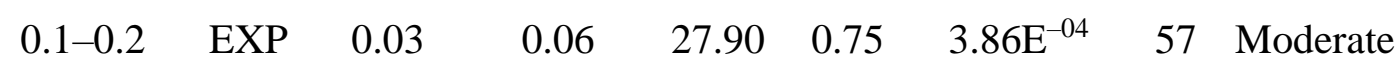

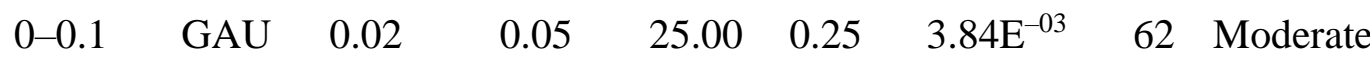

$\mathrm{Al}$

$\begin{array}{lllllllll}0.1-0.2 & \text { GAU } & 0.10 & 0.75 & 83.20 & 0.86 & 1.92 \mathrm{E}^{-01} & 87 & \text { Strong } \\ 0-0.1 & \text { ESF } & 0.02 & 0.28 & 111.20 & 0.47 & 1.34 \mathrm{E}^{-01} & 91 & \text { Strong }\end{array}$

$\mathrm{H}+\mathrm{Al}$

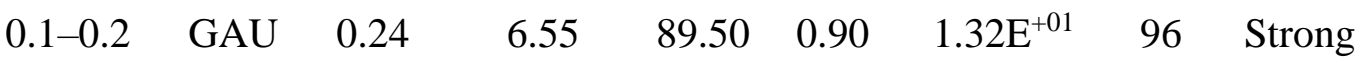

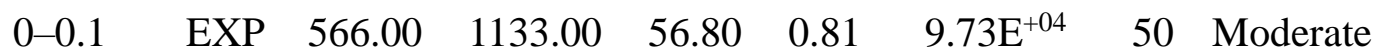

$\mathrm{P}$

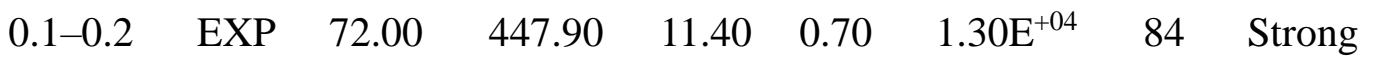

0-0.1 $\quad$ EXP $\quad 1454.00 \quad 3325.00 \quad 438.10 \quad 0.82 \quad 2.53 \mathrm{E}^{+05} \quad 56$ Moderate

$\mathrm{K}$

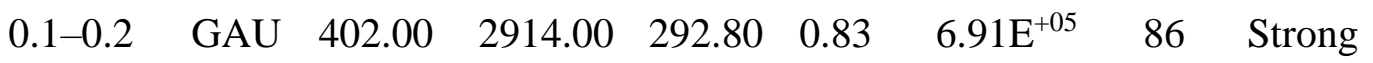

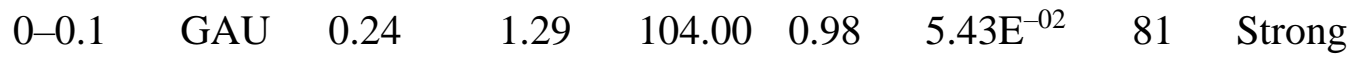

CTC

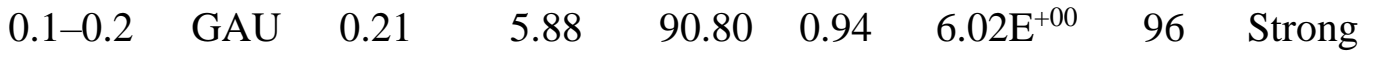

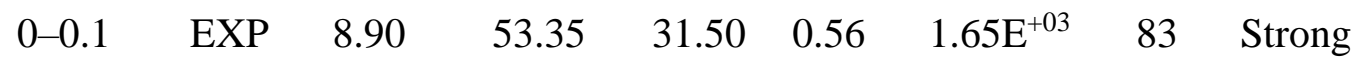

V

$\begin{array}{lllllllll}0.1-0.2 & \text { GAU } & 50.00 & 380.10 & 103.40 & 0.94 & 1.95 \mathrm{E}^{+04} & 87 & \text { Strong }\end{array}$

$\begin{array}{lllllllll}0-0.1 & \text { GAU } & 0.04 & 0.33 & 111.10 & 0.98 & 4.42 \mathrm{E}^{-03} & 89 & \text { Strong }\end{array}$

$\mathrm{Cu}$

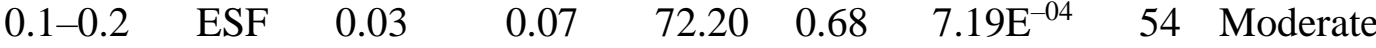

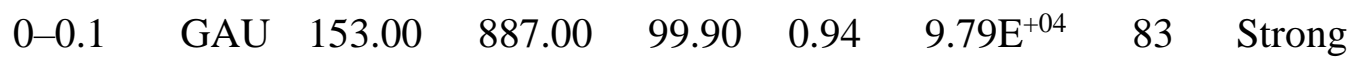

$\mathrm{Fe}$

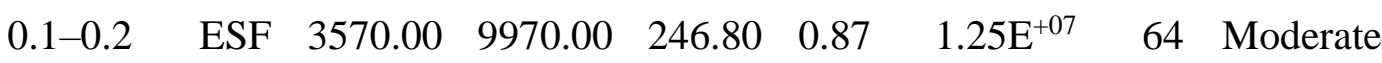

$\begin{array}{lllllllll}0-0.1 & \text { ESF } & 1.02 & 2.05 & 189.20 & 0.85 & 4.18 \mathrm{E}^{-01} & 50 & \text { Strong }\end{array}$

$\mathrm{Zn}$
$\begin{array}{lllllllll}0.1-0.2 & \text { EXP } & 0.16 & 1.30 & 8.10 & 0.29 & 2.61 E^{-01} & 88 & \text { Strong }\end{array}$

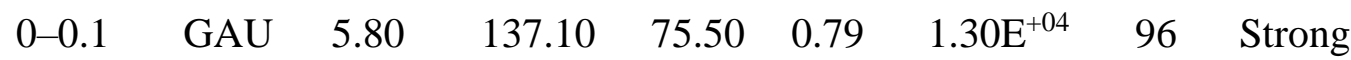

$\mathrm{Mn}$

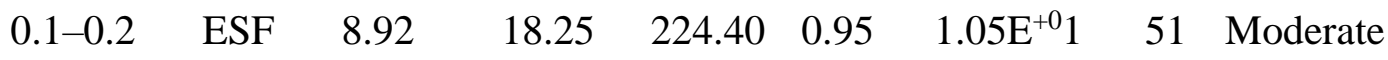

MDL - Theoretical model; C0 - nugget effect; $\mathrm{C} 0$ + $\mathrm{C}$ - landing; $\mathrm{A} 0$ - range (m); $\mathrm{R}^{2}$ - 
Coefficient of determination; SQR - Sum of squares of residues; SDI - Spatial dependency index; GDE - Degree of spatial dependence; GAU - Gaussian; EXP - Exponential; ESF Spherical.

In the present study, the spatial dependence interval for the soil properties under the study ranged from $20.9(\mathrm{pH})$ to $510.9(\mathrm{Ca})$ in the depth range of $0.0-0.1 \mathrm{~m}$. This indicates that the grid $(10 \times 10 \mathrm{~m})$ adopted for sampling was adequate to evaluate the spatial variability of the soil properties.

Evaluating the depth range of $0.1-0.2 \mathrm{~m}$, the spatial dependence for the evaluated attributes ranged from $8.7 \mathrm{~m}(\mathrm{Ca})$ to $292.8 \mathrm{~m}(\mathrm{~K})$. In addition to $\mathrm{Ca}, \mathrm{Zn}$ and $\mathrm{P}$ presented relatively low reach, being the first two inferior to the adopted grid. This shows that these elements are quite erratic in the area, probably due to the low mobility of $\mathrm{P}$ applied by fertilization and the low natural $\mathrm{Zn}$ content in the soil.

The depth range of $0.0-0.1 \mathrm{~m}$ presented, in general, a higher contents of the attributes than those in $0.1-0.2 \mathrm{~m}$, which may be related to the higher homogenization due to soil preparation (Marcolan et al., 2007) characterized by the successive applications of surface fertilizers and the rise of the water table, and by homogenizing the nutrients solubilized on the surface of the land. Large degrees of spatial dependence (range) imply that the soil collection distances can be further spaced, which can reduce the number of samples required, and consequently, the cost in the field with sampling. In general, the larger the spatial dependence interval, the higher the soil homogeneity.

\subsection{Cross-validation of the analyzed Attributes}

The regression coefficient (CR) of the silt attribute in the $0.1-0.2$ m layer was furthest from 1 (Table 3). For all the attributes, the standard errors (SE) were close to zero; this trend is associated with the other parameters. Bottega et al. (2013) found that the adjusted models had, in general, good precision in the estimation of values of these attributes in non-sampled places, thereby validating the obtained results. However, the values of the attributes, $\mathrm{Ca}$ (0.1-0.2 m), Mg, P, K, Cu (0.1-0.2 m), Fe (0.1-0.2 m) Zn and Mn (0.1-0.2 m) were furthest from zero. These results were related to the lowest coefficients of determination $\left(R^{2}\right)$ values of the models between the estimated and observed data (Table 3). This indicates that the models of these attributes were less accurate to estimates for non-sampled sites. For the attributes, $\mathrm{pH}, \mathrm{SOM}, \mathrm{Ca}, \mathrm{Mg}, \mathrm{Al}, \mathrm{H}+\mathrm{Al}, \mathrm{T}, \mathrm{V}$, and $\mathrm{Cu}$, intercept (Y) values close to zero were obtained, which, according to Lundgren et al. (2017), are the best because the closer to zero the value, the better the estimation.

Table 3. Parameters of the cross-validation for soil attributes in areas using surface and subgrade irrigation at Luiz Alves - GO

\begin{tabular}{cccccc}
\hline Attribute & Depth $(\mathrm{m})$ & $\mathrm{CR}$ & $\mathrm{SE}$ & $\mathrm{Y}$ & $\mathrm{R}^{2}$ \\
\hline Clay & $0-0.1$ & 1.02 & 0.06 & -5.95 & 0.61
\end{tabular}




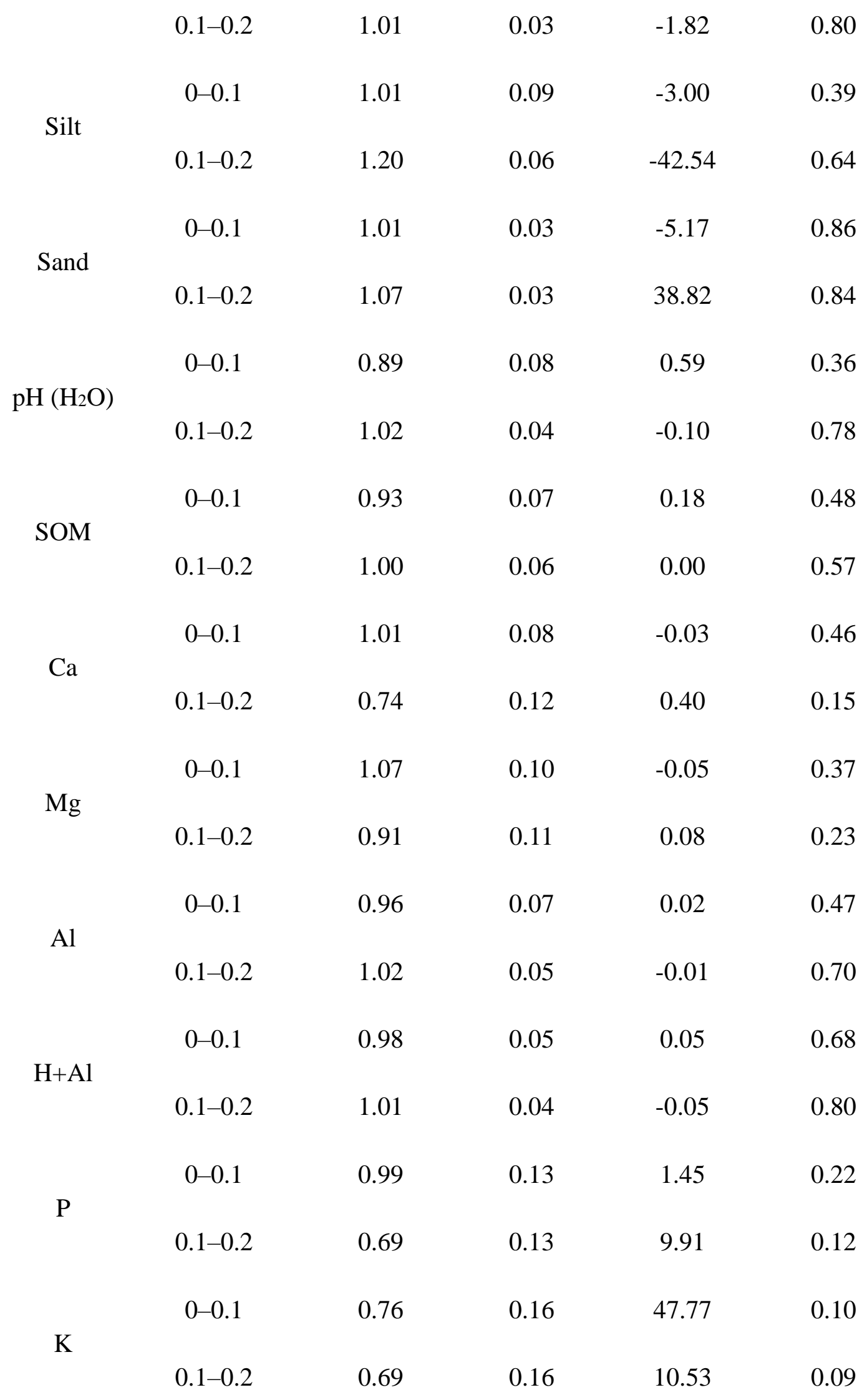




$\begin{array}{lllll}0-0.1 & 1.02 & 0.05 & -0.13 & 0.63\end{array}$

CTC

$\begin{array}{lllll}0.1-0.2 & 1.02 & 0.03 & -0.16 & 0.83 \\ 0-0.1 & 0.99 & 0.07 & 0.74 & 0.48\end{array}$

V

$\begin{array}{lllll}0.1-0.2 & 1.00 & 0.05 & -0.18 & 0.63 \\ 0-0.1 & 1.03 & 0.04 & -0.04 & 0.73\end{array}$

$\mathrm{Cu}$

$\begin{array}{lllll}0.1-0.2 & 0.97 & 0.10 & 0.01 & 0.31 \\ 0-0.1 & 1.03 & 0.05 & -8.43 & 0.66\end{array}$

$\mathrm{Fe}$

$\begin{array}{ccccc}0.1-0.2 & 1.03 & 0.09 & -12.60 & 0.41 \\ 0-0.1 & 0.88 & 0.10 & 0.33 & 0.25\end{array}$

$\mathrm{Zn}$

$\begin{array}{lllll}0.1-0.2 & 0.43 & 0.15 & 0.69 & 0.04\end{array}$

$\begin{array}{lllll}0-0.1 & 1.01 & 0.03 & -0.28 & 0.81\end{array}$

$\mathrm{Mn}$
$0.1-0.2$
0.90
0.11
0.75
0.23

CR - Regression coefficient; SE - Standard error; Y - Intercept; $\mathrm{R}^{2}$ - coefficient of determination.

\subsection{Iso-occurrence Maps of the Attributes Analyzed}

\subsubsection{Granulometry}

For the clay attributes, relatively low levels were recorded in the southern part of the area for the $0.0-0.1 \mathrm{~m}$ layer, indicating the sandy texture of the area (Figure 2). In the northern part of the area, the average texture was predominant according to Santos et al. (2015a). In general, the content of this attribute decreased as the depth increased, compared with the case of the two studied layers (Figure 2).

The spatial variations in the clay content and grain size in the study area may be related to the parent material (Ranjbar \& Jalali, 2016). The pedogenic processes that occur after alternate oxidation and reduction are known as ferrolysis (Brinkman, 1970) and are common in hydromorphic soils. The systematization process of the area usually exposes different soil horizons and may have contributed to the granulometric variability. 


\section{Mll Macrothink $\Lambda$ Institutem}

$0-0.1 \mathrm{~m}$
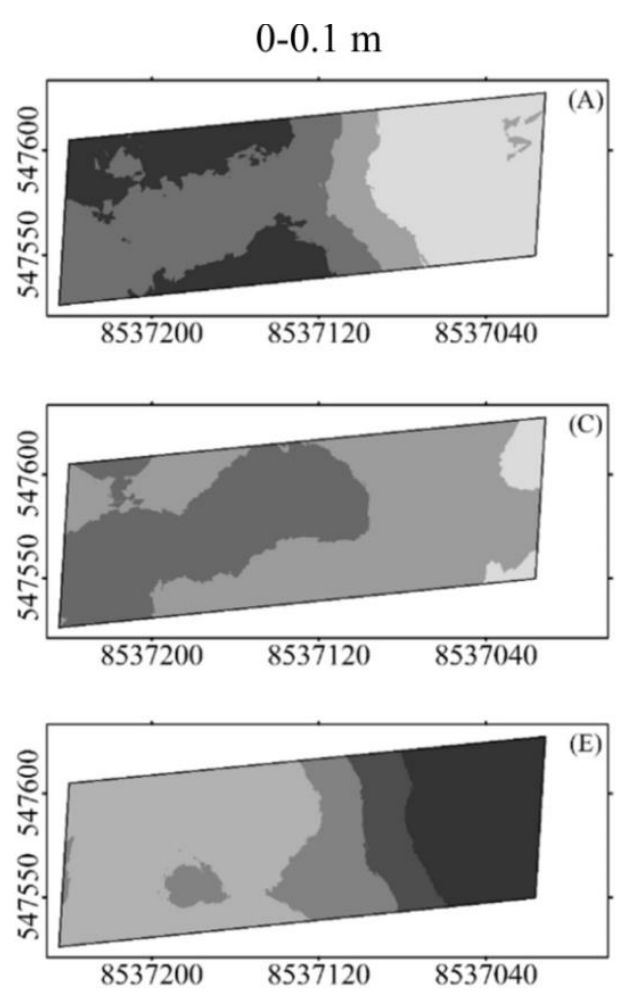

Journal of Agricultural Studies

ISSN 2166-0379

2021, Vol. 9, No. 3
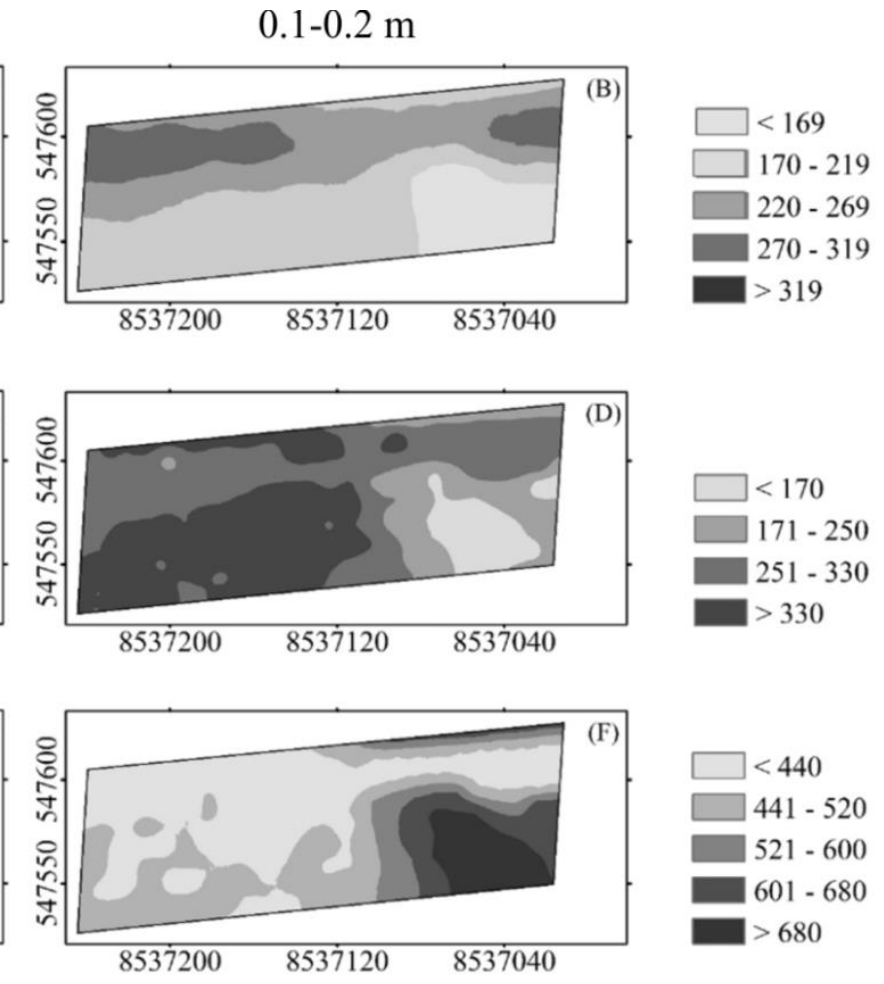

Figure 2. Maps using kriging interpolation to characterize soil, clay (A and B), silt (C and D), and sand $(\mathrm{E}$ and $\mathrm{F})$ attributes at depth ranges of $0-0.1 \mathrm{~m}$ and $0.1-0.2 \mathrm{~m}$ for each fraction, in areas of Luiz Alves - GO using surface irrigation and subirrigation methods

For silt, (Figures 2C and 2D) low levels were observed in the southern part of the area for the two depth ranges evaluated. For the northern part of the area, in the $0.1-0.2 \mathrm{~m}$ layer, there was a significant increase in one class $\left(>330 \mathrm{~g} \mathrm{~kg}^{-1}\right)$. These results are consistent with those obtained by Santos et al. (2015b), who studied Plinthosols in the southwest region of the State of Mato Grosso and found that the silt content increased with depth.

For sand, as expected, the results were the opposite of those for clay. The systematization process of the land with cuts and embankments exposed diverse texture horizons, which may be one of the reasons for the differences in granulometry, as discussed previously.

\subsubsection{Chemical Attributes: Macronutrients}

By analyzing the $\mathrm{pH}\left(\mathrm{H}_{2} \mathrm{O}\right)$ map, the homogeneity of this attribute in the area could be observed (Figures $3 \mathrm{~A}$ and $3 \mathrm{~B}$ ), with $\mathrm{pH}$ values ranging from 5.2 to 5.5 in the depth range of 0.0-0.1 m, which was characterized as average by Sousa \& Lobato (2004). For the 0.1-0.2 m layer, low $\mathrm{pH}\left(\mathrm{H}_{2} \mathrm{O}\right)(\leq 5.1)$ values were observed in the northern part of the area. Regarding the southern part, the $\mathrm{pH}$ varied from medium to high (5.2-6.6), with a predominance of adequate $\mathrm{pH}$ (5.6-6.3), as reported by the above-mentioned authors. Increasing the $\mathrm{pH}$ in acidic soils increases the $\mathrm{K}^{+}$levels, which is essential for overcoming the productivity issue of agricultural crops, owing to the toxicity generated by $\mathrm{Al}^{+3}$ and reduced $\mathrm{Fe}^{+2}$ 
(Ponnamperuma, 1972).

For SOM, relatively high concentrations (21-30 $\mathrm{g} \mathrm{kg}^{-1}$ ) were detected in the northern part of the area for the $0.0-0.1 \mathrm{~m}$ layer, which was considered adequate. In the southern part, medium levels (16-20 $\mathrm{g} \mathrm{kg}^{-1}$ ) (Sousa \& Lobato, 2004) were detected (Figure 3C). According to Sousa \& Lobato (2004), the $0.1-0.2 \mathrm{~m}$ layer presented low SOM levels $\left(<16 \mathrm{~g} \mathrm{~kg}^{-1}\right)$ in only one class in the whole area (Figure 3D).
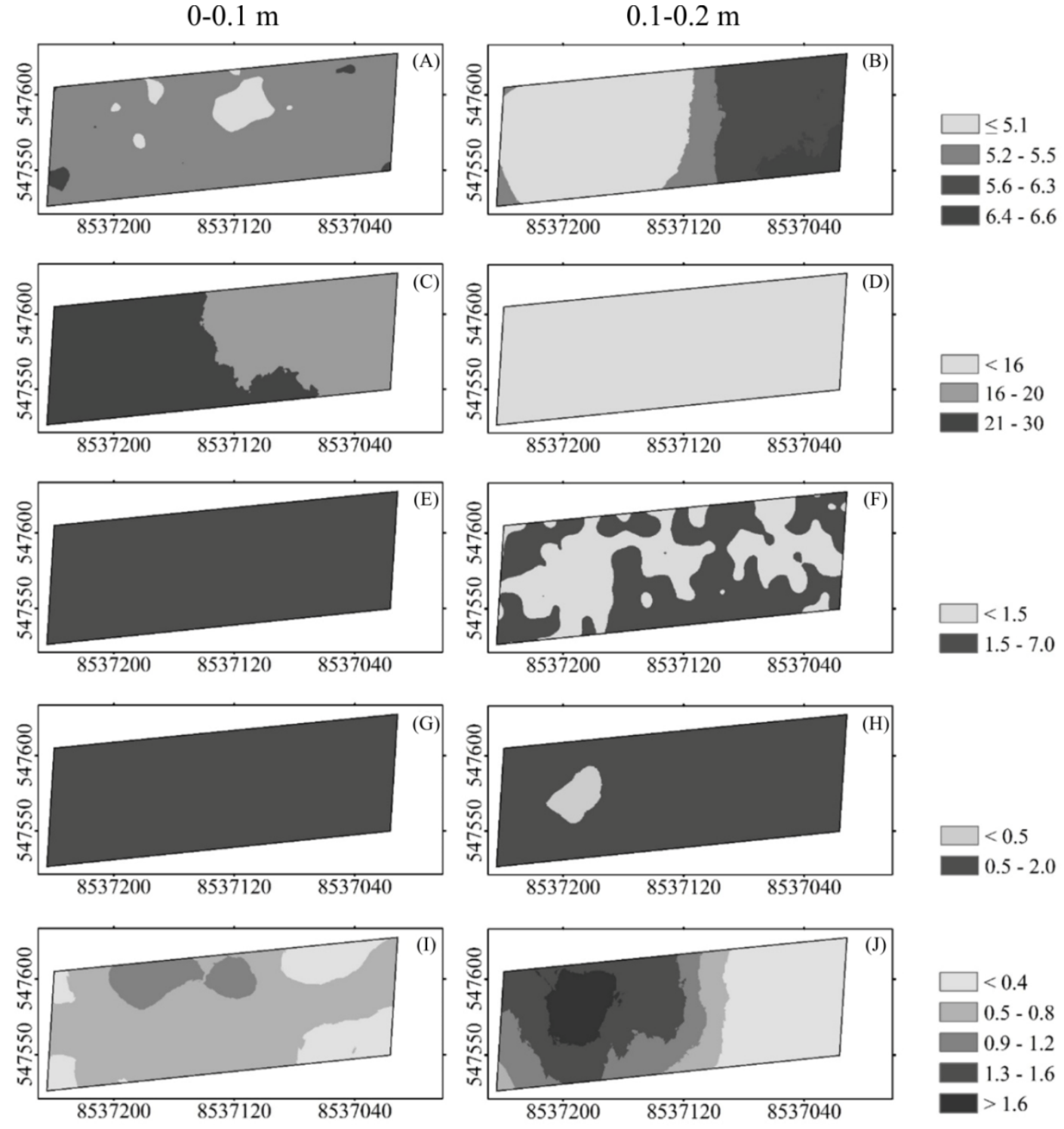

Figure 3. Maps using kriging interpolation to characterize the micronutrients, $\mathrm{pH}$ (A and $\mathrm{B}$ ), SOM (C and D), $\mathrm{Ca}(\mathrm{E}$ and $\mathrm{F}), \mathrm{Mg}(\mathrm{G}$ and $\mathrm{H})$, and $\mathrm{Al}$ (I and $\mathrm{J}$ ) at depth ranges of $0-0.1 \mathrm{~m}$ and 0.1-0.2 $\mathrm{m}$ for each fraction, in surface irrigated and subirrigated areas of Luiz Alves - GO

Normally, the SOM content is related to the deposition of vegetal residues on the soil surface (Acqua et al., 2013). It may also be related to the significant amount of clay detected, whose decomposition rate is significantly reduced by SOM, when compared to that of sandy soils, leading to its maintenance (Chapin et al., 2002). According to Xu et al. (2000), the conditions 
of reduction before and after the flood can increase the organic matter of the soil. However, the practice of burning crop residues by the farmers of Luiz Alves on the grounds that straw impairs the germination of planted crop seeds, contributes to the low input of crop residues, and may compromise this attribute in the medium or long term.

In general, the $\mathrm{Ca}$ contents in the two layers of soil analyzed varied slightly (Figures $3 \mathrm{E}$ and $3 \mathrm{~F}$ ). This may be due to the good incorporation of limestone with plowshares up to $0.15 \mathrm{~m}$, and the effect of flooding. At the depth range of $0.0-0.1 \mathrm{~m}$, the Ca contents were in the appropriate range $\left(1.5-7.0 \mathrm{cmol}_{\mathrm{c}} \mathrm{dm}^{-3}\right)$, based on Sousa \& Lobato (2004). At the depth range of $0.1-0.2 \mathrm{~m}$, the heterogeneity of the contents was observed; moreover, the detected content was considered adequate for this element $\left(>1.5 \mathrm{cmol}_{\mathrm{c} \mathrm{dm}}^{-3}\right)$, except in the large spots located along the central axis of the area, where it was considered low (Figure 3F). To correct these low $\mathrm{Ca}$ levels and not compromise crop productivity, liming should be avoided. In floodplain areas under flood conditions, the changes in the $\mathrm{Ca}$ and $\mathrm{Mg}$ concentrations were considered small according to Fageria et al. (2011), which corroborates the present study.

For $\mathrm{Mg}$, (Figures 3G and 3H), there was practically no formation of content classes for each soil layer evaluated, although the levels were distinct in each one. For both depths, the contents for this nutrient were adequate $\left(0.5-2.0 \mathrm{cmol}_{\mathrm{c}} \mathrm{dm}^{-3}\right)$ throughout the area (Sousa \& Lobato, 2004), except for a small spot in the deeper layer. Relatively low clay contents may influence this result due to the low adsorption of this nutrient.

For $\mathrm{Al}^{+3}$, the lowest concentrations were detected in the southern region of the area for both strata evaluated (Figures 3I and 3J). At the depth range of $0.0-0.1 \mathrm{~m}$, a significant part of the area presented $\mathrm{Al}^{+3}$ levels in the range of 0.5 to $0.8 \mathrm{cmol}_{\mathrm{c}} \mathrm{dm}^{-3}$. In the northern part of the area, in the $0.1-0.2 \mathrm{~m}$ layer, the concentrations of $\mathrm{Al}$ were predominantly in the range of 0.9 to $1.6 \mathrm{cmol}_{\mathrm{c}} \mathrm{dm}^{-3}$, due to the correction of this element by liming. This may be related to the relatively high clay content, which has a high cation retention capacity. This information is useful for $\mathrm{Al}^{+3}$ correction at variable rates using limestone.

Bitencourt et al. (2016) investigated lowland soils and recorded relatively high $\mathrm{Al}^{+3}$ levels after levelling the terrain. Additionally, Santos et al. (2015b) studied Plinthosols in the southwest region of the state of Mato Grosso and recorded relatively high levels of $\mathrm{Al}^{+3}$ as the depth increased.

Low potential acidity $(\mathrm{H}+\mathrm{Al})$ levels were detected in the depth range of $0.0-0.1 \mathrm{~m}$ compared to that in the $0.1-0.2 \mathrm{~m}$ layer (Figure $4 \mathrm{~A}$ and $4 \mathrm{~B}$ ). In the $0.1-0.2 \mathrm{~m}$ layer, the northern part presented low potential acidity levels, whereas in the south, the levels increased gradually. High potential acidity levels imply that high amounts of limestone would be required to correct the acidity by the high soil buffering effect. Similar results were found by Anjos et al. (2007) and Coringa et al. (2012) in Plintossolo Argilúvico (Plinthosols). 


\section{Macrothink Mnstitute"'}
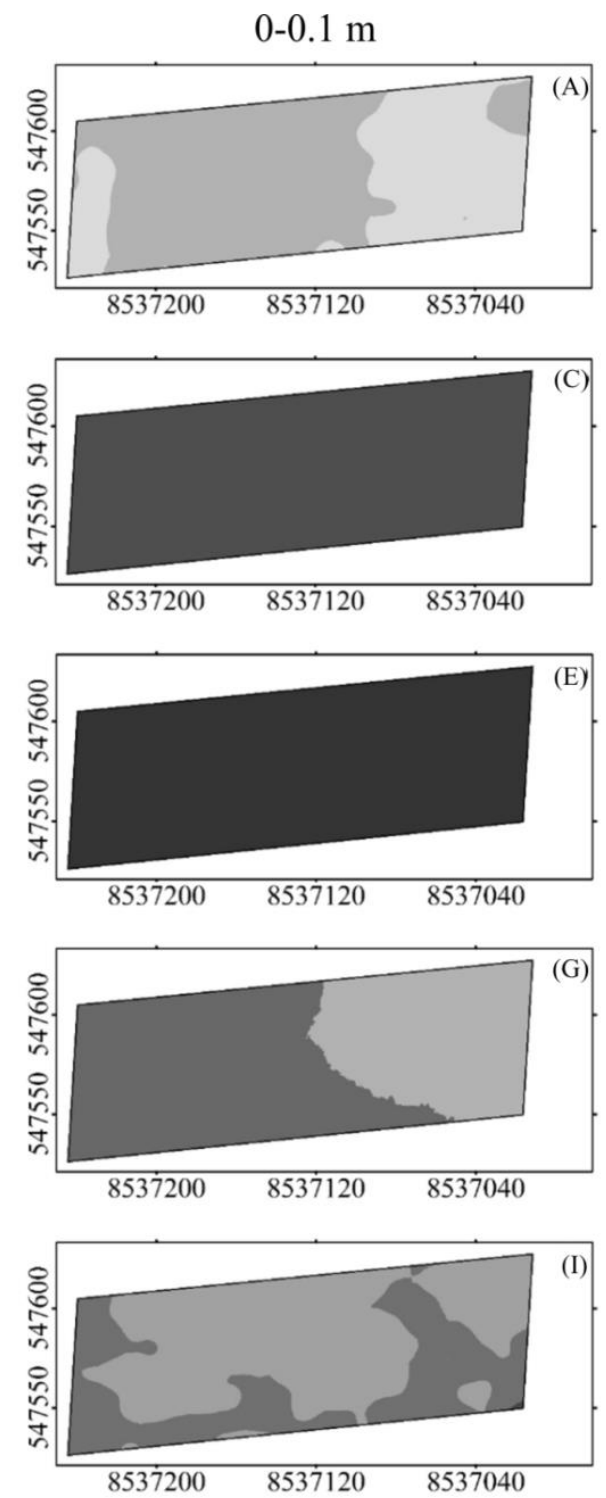

Journal of Agricultural Studies

ISSN 2166-0379

2021, Vol. 9, No. 3
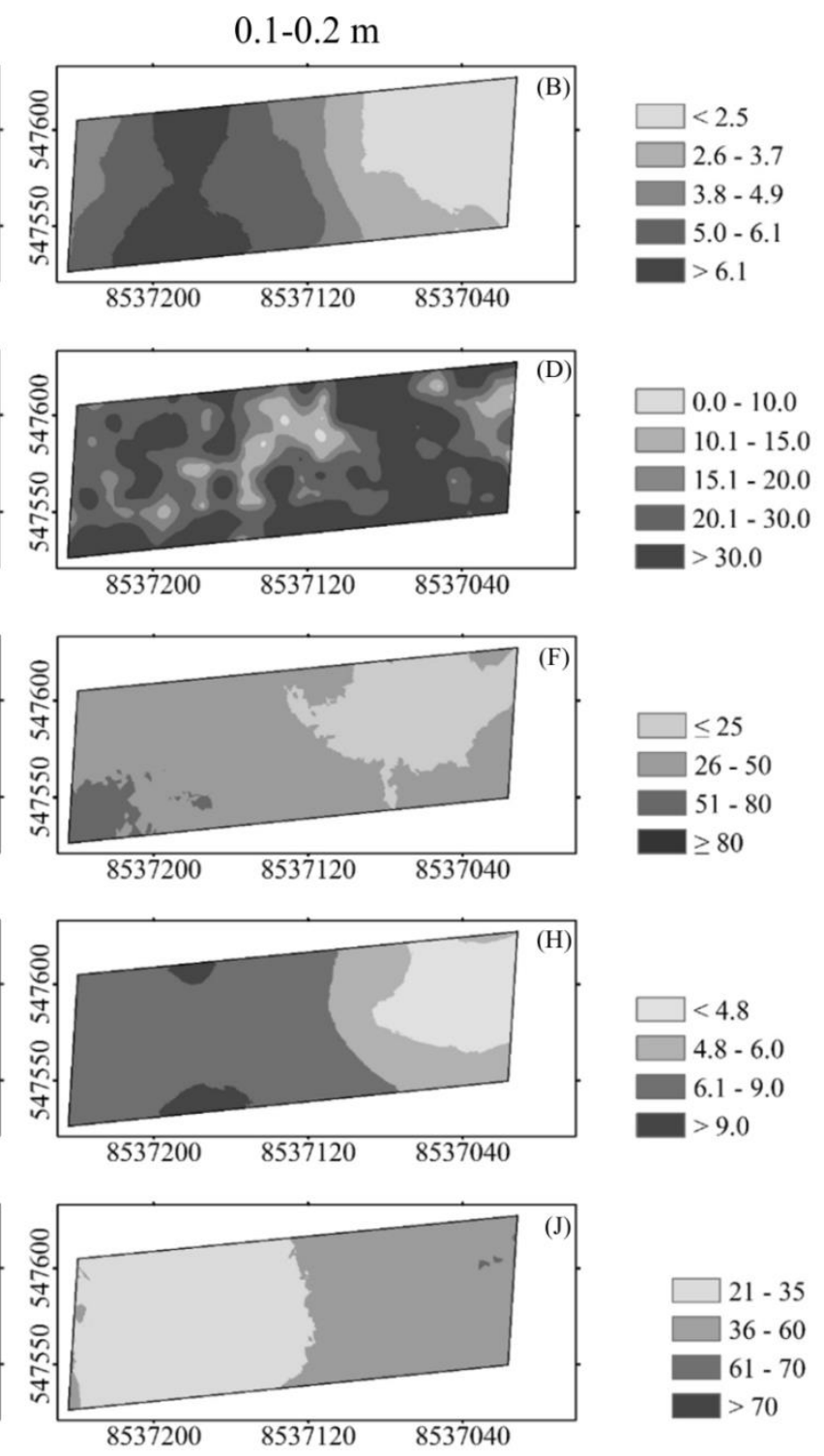

Figure 4. Maps using kriging interpolation to characterize the micronutrients, $\mathrm{H}+\mathrm{Al}$ ( $\mathrm{A}$ and $\mathrm{B}), \mathrm{P}(\mathrm{C}$ and $\mathrm{D}), \mathrm{K}(\mathrm{E}$ and $\mathrm{F}), \mathrm{CTC}(\mathrm{G}$ and $\mathrm{H})$, and $\mathrm{V}$ (I and $\mathrm{J})$ at depth ranges of $0-0.1 \mathrm{~m}$ and $0.1-0.2 \mathrm{~m}$ for each fraction, in surface irrigated and subirrigated areas of Luiz Alves - GO

For P (Figures 4C and 4D), in the most superficial layer, throughout the area, the obtained values were above $70 \mathrm{mg} \mathrm{dm}^{-3}$, which is considered high (> $30 \mathrm{mg} \mathrm{dm}^{-3}$ ). In the depth range of $0.1-0.2 \mathrm{~m}$, the P content was lower than that in the most superficial layer (Figure 4D). Thus, considering the clay content as having medium texture, the interpretation of the $\mathrm{P}$ content was high for most of the area. These determined high $\mathrm{P}$ content may be associated with low $\mathrm{P}$ fixation in the studied environment and successive crop fertilization, often without regard for interpretation and recommendation of soil analysis. Parfitt et al. (2009) studied lowland soils in Capão do Leão, state of Rio Grande do Sul, Brazil, and recorded levels of P from 4.5 to $26.1 \mathrm{mg} \mathrm{dm}^{-3}$, which were very high for rice farming on irrigated lands.

For $\mathrm{K}$, in the $0.0-0.1 \mathrm{~m}$ layer, it can be observed that the content of this element presents a single interpretation class on the map (Figure 4E), with high levels $\left(\geq 80 \mathrm{mg} \mathrm{dm}^{-3}\right.$ ) (Sousa \& 
Lobato, 2004), with concentrations above $151 \mathrm{mg} \mathrm{dm}^{-3}$. The spatial differences of this nutrient can be related to the heterogeneity of the wetting of the area, due to the elevation of the water table, which influences the vertical movement of the same. At the depth range of $0.1-0.2 \mathrm{~m}$, in the southern part of the area, there was a large spot with low K levels $(<25 \mathrm{mg}$ $\mathrm{dm}^{-3}$ ), whereas the rest of the area contained medium levels $\left(26-50 \mathrm{mg} \mathrm{dm}^{-3}\right.$ ) (Sousa \& Lobato, 2004) (Figure 4F).

As for CTC (Figures 4G and 4H), high concentrations were observed in the northern portion of the study area for both depths with adequate values $\left(6.1-9.0 \mathrm{cmol}_{\mathrm{c}} \mathrm{dm}^{-3}\right)$. For the southern region in the $0.0-0.1 \mathrm{~m}$ layer, the CTC levels were medium $\left(4.8-6.0 \mathrm{cmol}_{\mathrm{c}} \mathrm{dm}^{-3}\right)$, and for the relatively deep layer, values between low and medium were detected according to Sousa \& Lobato (2004). These results indicate that, in the southern part, soil fertility is lower than in the northern part, as confirmed by higher sand content (Figures 2E and 2F), lower organic matter content (Figures 3C and 3D), lower $\mathrm{Ca}$ content (Figures 3E and 3F), and lower $\mathrm{K}$ content (Figures 4E and 4F). Increasing the soil organic matter is one of the best alternatives for increasing CTC and, consequently, the fertility of the area.

For the base saturation attribute $(\mathrm{V} \%)$, in the depth of $0.0-0.1 \mathrm{~m}$, much of the study area presented adequate values (36-60\%) and the rest, high values (61-70\%) (Figures 4I and 4J). In the $0.1-0.2 \mathrm{~m}$ layer, it is observed that the northern region has mean values $(21-35 \%)$ and the southern region (Figure $4 \mathrm{~J}$ ), higher values, which are adequate, according to Sousa \& Lobato (2004). Based on the results, the eutrophic character $(\mathrm{V}>50 \%)$ of the soil in the study area or around it, mainly in the $0.0-0.1 \mathrm{~m}$ layer, prevails, indicating good fertility. Attention should be given to fertility management to increase base saturation, particularly in the northern part of the area.

\subsubsection{Chemical Attributes: Micronutrients}

In relation to the $\mathrm{Cu}$ attribute, in the $0-0.1 \mathrm{~m}$ layer, a single $\mathrm{Cu}$ content class was found, which was higher than $1.0 \mathrm{mg} \mathrm{dm}^{-3}$ (Figures 5A and 5B), and considered high $\left(>0,8 \mathrm{mg} \mathrm{dm}^{-3}\right)$. However, for the relatively deep layer, low $\mathrm{Cu}$ levels were detected $\left(<0.4 \mathrm{mg} \mathrm{dm}^{-3}\right)$. Emphatically, in most of the points sampled, this nutrient was undetectable. The low content of this nutrient may be related to the unavailability of the source material (sediments), the higher sandy soil content, and the increase in $\mathrm{pH}$ (Novais et al., 2007).

For $\mathrm{Fe}$, in the layer of $0.0-0.1 \mathrm{~m}$, significant homogeneity is observed, with Fe predominating in almost all parts of the area (except a spot in the southern part), in the range of 315 to 365 $\mathrm{mg} \mathrm{kg}{ }^{-1}$ (Figure 5C). In the 0.1-0.2 m layer, the content decreased from north to south; however, values in excess of $416 \mathrm{mg} \mathrm{kg}^{-1}$ predominated in almost all parts of the area. This may be due to the effect of the reducing conditions, which increased the availability of this element in the soil (Verma et al., 2013). 

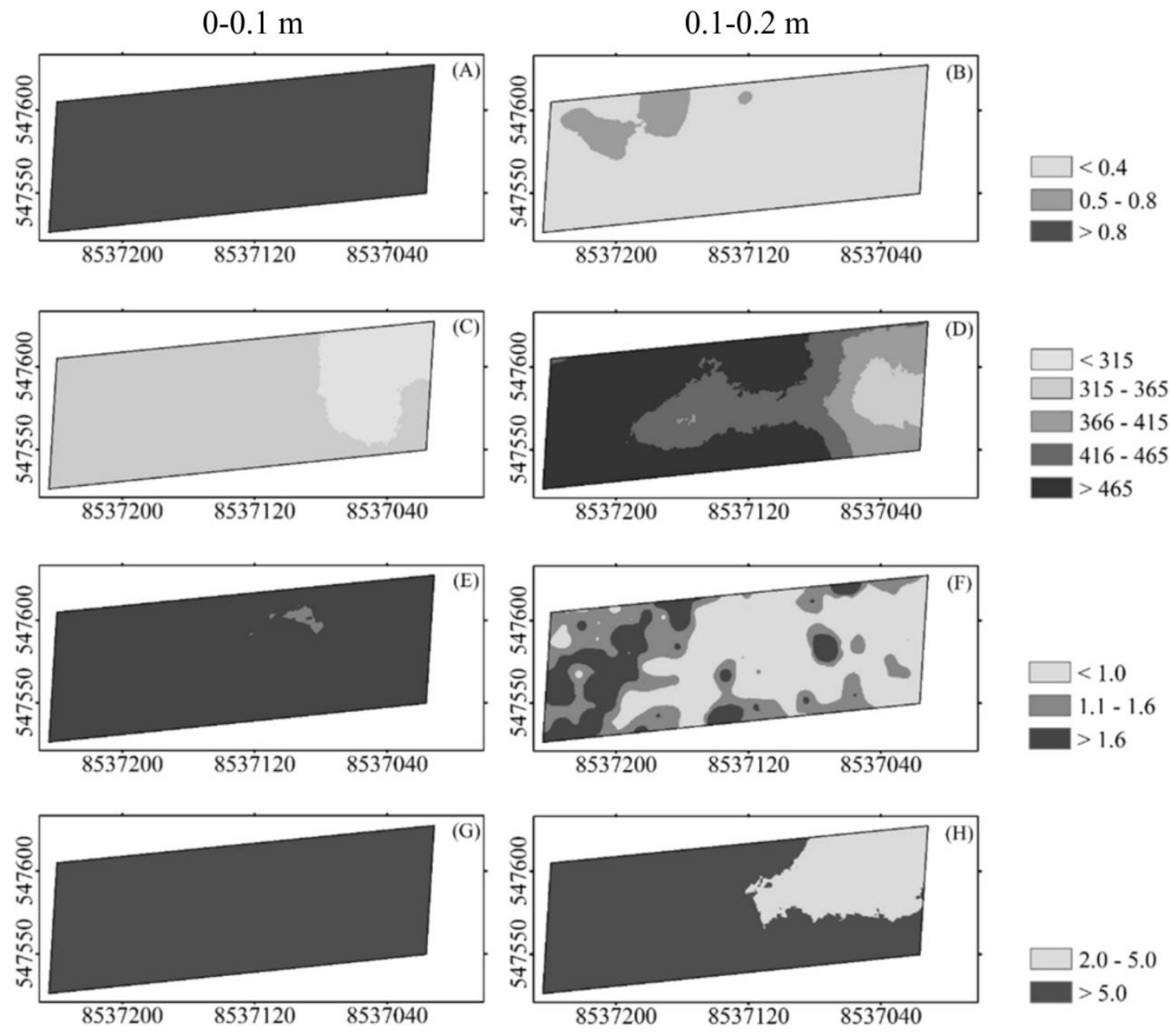

Figure 5. Maps using kriging interpolation to characterize the micronutrients, $\mathrm{Cu}(\mathrm{A}$ and $\mathrm{B})$, $\mathrm{Fe}(\mathrm{C}$ and $\mathrm{D}), \mathrm{Zn}(\mathrm{E}$ and $\mathrm{F})$, and $\mathrm{Mn}(\mathrm{G}$ and $\mathrm{H})$ at depth ranges of $0-0.1 \mathrm{~m}$ and $0.1-0.2 \mathrm{~m}$ for each fraction, in surface irrigated and subirrigated areas of Luiz Alves - GO

For $\mathrm{Zn}$ (Figures $5 \mathrm{E}$ and $5 \mathrm{~F}$ ), in the layer of $0.0-0.1 \mathrm{~m}$, significant homogeneity of this nutrient was observed, with contents above $1.6 \mathrm{mg} \mathrm{dm}^{-3}$ in almost all parts of the area, which was considered high (Sousa \& Lobato, 2004). In the 0.1-0.2 m layer, the spatial distribution of the $\mathrm{Zn}$ content was considerably uneven, with levels below $1.0 \mathrm{mg} \mathrm{dm}^{-3}$ predominating in almost all parts of the area, which was considered low, except for the portion of the area with medium (1.1) to high $\left(>1.6 \mathrm{mg} \mathrm{dm}^{-3}\right)$ levels. This may be related to the fact that the availability of $\mathrm{Zn}$ decreases in soils with high levels of sand and P. In addition, Fageria et al. (2003) highlighted the $\mathrm{pH}$ increase and lack of soil aeration due to flooding, removal of the soil layer in the systematization process, and low organic matter content.

For Mn, (Figures 5G and 5H), for the most superficial layer, high levels (>5.0 $\mathrm{mg} \mathrm{dm}^{-3}$ ) were detected throughout the area, with only one class. In relation to the $0.1-0.2 \mathrm{~m}$ layer, in most parts of the area, the detected contents were high, except for the southern part, where the contents were medium $\left(2.0-5.0 \mathrm{mg} \mathrm{dm}^{-3}\right)$. 
Reduction environments favor the availability of $\mathrm{Mn}$, where it remains in the form of $\mathrm{Mn}^{+2}$ (Novais et al., 2007; Souza, 2017). In this case, it is suggested that the sites in the study area that presented variations in the values of this element may be associated with differences in the degree of hydromorphism. These differences are due to the uneven height of the water table during the dry season when the area is irrigated by the elevation of the water table in the network of channels. According to Albuquerque et al. (2001) values above $20 \mathrm{ppm}$ are considered to be toxic, and Mn-levels correction by liming is necessary.

\subsection{Ideal Number of Samples}

For the depth range of $0.0-0.1 \mathrm{~m}$, there is a tendency for smaller amounts of simple samples to form composites, considering the error in the mean (10,15, and 20\%) estimation (Table 4). It can be observed that in the 0.1-0.2 m layer, considering the largest error (20\%), Al, P, K, $\mathrm{Cu}$, and $\mathrm{Zn}$ presented very high numbers of simple samples for each sample, making it unfeasible to meet the required quantity. This high value is related to the high $\mathrm{CV}$ of the nutrients under study (Table 1).

Table 4. Number of subsamples per compost as a function of the error allowed around the mean to evaluate soil attributes in the depth ranges of $0-0.1 \mathrm{~m}$ and $0.1-0.2 \mathrm{~m}$, in flooded and subsurface irrigated areas of Luiz Alves - GO.

\begin{tabular}{|c|c|c|c|c|c|c|}
\hline \multirow{3}{*}{ Attribute } & \multicolumn{6}{|c|}{ Error in relation to average $(\%)$} \\
\hline & \multicolumn{2}{|c|}{10} & \multicolumn{2}{|c|}{15} & \multicolumn{2}{|c|}{20} \\
\hline & $0-0.1 \mathrm{~m}$ & $0.1-0.2 \mathrm{~m}$ & $0-0.1 \mathrm{~m}$ & $0.1-0.2 \mathrm{~m}$ & $0-0.1 \mathrm{~m}$ & $0.1-0.2 \mathrm{~m}$ \\
\hline Clay & 30 & 32 & 13 & 14 & 7 & 7 \\
\hline Silt & 24 & 27 & 11 & 12 & 6 & 8 \\
\hline Sand & 14 & 21 & 6 & 9 & 4 & 5 \\
\hline $\mathrm{pH}\left(\mathrm{H}_{2} \mathrm{O}\right)$ & 1 & 6 & 1 & 3 & 1 & 1 \\
\hline SOM & 6 & 25 & 3 & 11 & 1 & 6 \\
\hline $\mathrm{Ca}$ & 15 & 26 & 7 & 11 & 4 & 6 \\
\hline $\mathrm{Mg}$ & 35 & 36 & 15 & 16 & 9 & 9 \\
\hline $\mathrm{Al}$ & 74 & 242 & 33 & 108 & 19 & 61 \\
\hline $\mathrm{H}+\mathrm{Al}$ & 13 & 77 & 6 & 34 & 3 & 19 \\
\hline
\end{tabular}




\begin{tabular}{ccccccc}
$\mathrm{P}$ & 31 & 167 & 14 & 74 & 8 & 42 \\
$\mathrm{~K}$ & 18 & 225 & 8 & 100 & 5 & 56 \\
$\mathrm{CTC}$ & 7 & 28 & 3 & 12 & 2 & 7 \\
$\mathrm{~V}$ & 5 & 52 & 2 & 23 & 1 & 13 \\
$\mathrm{Cu}$ & 25 & 855 & 11 & 380 & 6 & 214 \\
$\mathrm{Fe}$ & 2 & 12 & 1 & 5 & 1 & 3 \\
$\mathrm{Zn}$ & 85 & 343 & 38 & 153 & 21 & 86 \\
$\mathrm{Mn}$ & 112 & 108 & 50 & 48 & 28 & 27 \\
\hline
\end{tabular}

(1) $\mathrm{n}=\left(\mathrm{t}^{2} \mathrm{~s}^{2} / \mathrm{d}^{2} \mathrm{~m}^{2}\right)$ according Thompson (1992).

Based on the clay content, the number of subsamples required to form composites ranged from 7 to 32 simple samples in the $0.0-0.1 \mathrm{~m}$ layer considering a $10 \%$ to $20 \%$ error in relation to the mean. For a $20 \%$ error in the $0.0-0.1 \mathrm{~m}$ layer, the quantity was 19 simple samples per composite for granulometry and macronutrients and 28 subsamples for micronutrients. Considering the 0.1-0.2 m layer, 19 samples are needed for macronutrients, except $\mathrm{Al}, \mathrm{P}$, and $\mathrm{K}$, and 27 subsamples for micronutrients, except $\mathrm{Cu}$ and $\mathrm{Zn}$. The number of samples collected in a homogeneous plot to represent the area depends on the precision of the objective sampling (Rozane et al., 2011).

\section{Conclusion}

All the properties of the studied soil exhibited spatial dependence. New studies in the area can be performed using a sample grid with a sampling interval of $20 \mathrm{~m}$, based on the results of the $0.0-0.1 \mathrm{~m}$ layer.

The 0.0-0.1 m layer has a more homogeneous spatial distribution of nutrients compared to that of the $0.1-0.2 \mathrm{~m}$ layer. High levels of nutrients $\mathrm{P}, \mathrm{K}, \mathrm{Fe}$, and $\mathrm{Mn}$ were detected in the $0.0-0.1 \mathrm{~m}$ layer; low SOM levels were detected in the $0.1-0.2 \mathrm{~m}$ layer, and attention must be paid to adequate management.

The northern region differs from the southern region of the area in terms of soil granulation, $\mathrm{pH}\left(\mathrm{H}_{2} \mathrm{O}\right), \mathrm{Al}, \mathrm{H}+\mathrm{Al}, \mathrm{CTC}$, and Fe attributes, which can be used in decision making in soil fertility management and in carrying out experiments. The ideal number of subsamples for each composite sample is 19 for granulometry and macronutrients in the layers of $0.0-0.1 \mathrm{~m}$ and $0.1-0.2 \mathrm{~m}$, with the exception of $\mathrm{Al}, \mathrm{P}$, and $\mathrm{K}$ for this last layer, and 28 subsamples for the micronutrients studied for the two layers except $\mathrm{Cu}$ and $\mathrm{Zn}$ in the 0.1-0.2 m layer. 


\section{Acknowledgments}

To IF Goiano to financially support the study. To Emater for the availability of the area for the study.

\section{References}

Acqua, N. H. D., Silva, G. P., Benites, V. M., Assis, R. L., \& Simon, G. A. (2013). Métodos de amostragem de solos em áreas sob plantio direto no Sudoeste Goiano. Revista Brasileira de Engenharia Agrícola e Ambiental, 17(2), 117-122. https://doi.org/10.1590/S1415-43662013000200001

Aidar, H., Kluthcouski, J. \& Stone, L. F. (2002). Produção do feijoeiro comum em várzeas tropicais. Santo Antônio do Goiás: Embrapa Arroz e Feijão. p. 305.

Albuquerque, M. M., Vieira, J. C. \& Lemos, J. W. V. (2001). Recomendações técnicas para o cultivo do feijoeiro no Estado do Alagoas. Aracaju: Embrapa Tabuleiros Costeiros. p. 34.

Andres, A., Concenço, G., Theisen, G., Galon, L., \& Tesio, F. (2012). Management of red rice (Oryza sativa) and barnyardgrass (Echinochloa crus-galli) grown with sorghum with reduced rate of atrazine and mechanical methods. Experimental Agriculture, 48(4), 587-596. https://doi.org/10.1017/S0014479712000671

Anjos, L. H. C., Pereira, M. G., Pérez, D. V., \& Ramos, D. P. (2007). Caracterização e classificação de Plintossolos no município de Pinheiro-MA. Revista Brasileira de Ciência do Solo, 31(5), 1035-1044. https://doi.org/10.1590/S0100-06832007000500020

Barik, K., Aksakal, E. L., Islam, K. R., Sari, S., \& Angin, I. (2014). Spatial variability in soil compaction properties, associated with field traffic operations. Catena, 120, 122-133. https://doi.org/10.1016/j.catena.2014.04.013

Benedetto, D., Castrignano, A., Sollitto, D., Modugno, F., Bettafuoco, G., \& Papa, G. (2012). Integrating geophysical and geostatistical techniques to map the spatial variation of clay. Geoderma, 171-172, 53-63. https://doi.org/10.1016/j.geoderma.2011.05.005

Bitencourt, D. G. B., Barros, W. S., Timm, L. C., She, D., Penning, L. H., Parfitt, J. M. B., \& Reichardt, K. (2016). Multivariate and geostatistical analyses to evaluate lowland soil levelling effects on physico-chemical properties. Soil and Tillage Research, 156, 63-73. https://doi.org/10.1016/j.still.2015.10.004

Bogunovic, I., Pereira, P., \& Brevik, E. C. (2017). Spatial distribution of soil chemical properties in an organic farm in Croatia. Science of the Total Environment, 584, 535-545. https://doi.org/10.1016/j.scitotenv.2017.01.062

Bottega, E. L., Queiroz, D. M., Pinto, F. A. C., \& Souza, C. M. A. (2013). Variabilidade espacial de atributos do solo em sistema de semeadura direta com rotação de culturas no cerrado brasileiro. Revista Ciência Agronômica, 44(1), 1-9. https://doi.org/10.1590/S1806-66902013000100001

Brinkman, R. Ferrolysis, a hydromorphic soil-forming process. (1970). Geoderma, 3, 
199-206. https://doi.org/10.1016/0016-7061(70)90019-4

Cambardella, C. A., Moorman, T. B., Novak, J. M., Parkin, T. B., Karlen, D. L., Turco, R. F., $\&$ Konopka, A. E. (1994). Field-scale variability of soil properties in Central Iowa Soils. Soil Science Society of America Journal, 58(5), 1501-1511. https://doi.org/10.2136/sssaj1994.03615995005800050033x

Canton, L. E. D., Guedes, L. P. C., \& Uribe-Opazo, M. A. (2021). Spatial and multivariate analysis of soybean yield in the state of Paraná-Brazil. Journal of Agricultural Studies, 9(1), 357-376. https://doi.org/10.5296/jas.v9i1.17473

Cassol, G. V. (2017). Sistemas de implantação, irrigação e alterações fisiológicas de plantas de soja sob cultivo em terras baixas. PhD diss., Universidade Federal de Santa Maria. p. 142.

Chapin, F. S., Matson, P. A., \& Vitousek, P. M. (2002). Principles of terrestrial ecosystem ecology. (2nd ed.). New York: Springer. p. 529.

Coringa, E. A. O., Couto, E. G., Perez, X. L. O., \& Torrado, P. V. (2012). Atributos de solos hidromórficos no pantanal norte Matogrossense. Acta Amazonica, 472(1), 19-28. https://doi.org/10.1590/S0044-59672012000100003

Donagema, G. K., Campos, D. V. B., Calderano, S. B., Teixeira, W. G., \& Viana, J. H. (2011). Manual de métodos de análise de solo. (2nd ed.). Rio de Janeiro: Embrapa Solos. p. 230.

Esri. ArcGIS Desktop (Release 10.2.2). (2014). Redlands, California: Environmental Systems Research Institute, Inc.

Fageria, N. K., Carvalho, G. D., Santos, A. B., Ferreira, E. P. B., \& Knupp, A. M. (2011). Chemistry of lowland rice soils and nutrient availability. Communications in Soil Science and Plant Analysis, 42(16), 1913-1933. https://doi.org/10.1080/00103624.2011.591467

Fageria, N. K., Santos, A. B., \& Stone, L. F. (2003). Manejo do zinco. In N. K. Fageria, A. B. Santos, \& L. F. Stone (Eds.), Manejo da fertilidade do solo para o arroz irrigado, (pp. 167-186). Santo Antônio de Goiás: Embrapa Arroz e Feijão.

GOIÁS. Projeto de Irrigação Luís Alves do Araguaia/PILAA. Accessed December 28, 2020. http://www.sgc.goias.gov.br/upload/arquivos/2017-07/projeto-de-irrigacao-luis-alves.pdf

GRiSP. (2013). Rice Almanac. (4th ed.). Los Baños: International Rice Research Institute. p. 283.

Haefele, S. M., Kato, Y., \& Singh, S. (2016). Climate ready rice: augmenting drought tolerance with best management practices. Field Crops Research, 190, 60-69. https://doi.org/10.1016/j.fcr.2016.02.001

Haefele, S. M., Nelson, A., \& Hijmans, R. J. (2014). Soil quality and constraints in global rice production. Geoderma, 235, 250-259. https://doi.org/10.1016/j.geoderma.2014.07.019

Jiménez-Aguirrea, M. T., Isidoro, D., \& Usón, A. (2018). Soil variability in La Violada Irrigation District (Spain): I Delineating soil units for irrigation. Geoderma, 311, 78-90. 
https://doi.org/10.1016/j.geoderma.2017.04.025

Kerry, R., Oliver, M. A., \& Frogbrook, Z. L. (2010). Sampling precision agriculture. In M. A. Oliver (Eds.), Geostatistical applications for precision agriculture (pp. 35-63). Heidelberg: Springer.

Kischel, E., Fidelis, R. R., Santos, M. M., Brandão, D. R., Cancellier, E. R., \& Nascimento, I. R. (2011). Efeito do nitrogênio em genótipos de arroz cultivados em várzea úmida do Estado $\begin{array}{lllr}\text { do Tocantins. } & \text { Revista } & \text { Ceres, } & \text { 84-89. }\end{array}$ https://doi.org/10.1590/S0034-737X2011000100013

Köppen, W. P. Grundriss der Klimakunde. Berlin: Walter de Gruyter, 1931, 390 p.

Lundgren, W. J. C., Silva, J. A. A., \& Ferreira, R. L. C. (2017). A precisão da estimativa do erro da krigagem pela validação cruzada. Floresta e Ambiente, 24, e00124114. https://doi.org/10.1590/2179-8087.124114

Marcolan, A. L., Anghinoni, I., Fraga, T. I., \& Leite, J. G. D. B. (2007). Recuperação de atributos físicos de um Argissolo em função do seu revolvimento e do tempo de semeadura direta. Revista Brasileira de Ciência do Solo, 31(3), 571-579. https://doi.org/10.1590/S0100-06832007000300017

Marques Júnior, J., Siqueira, D. S., Camargo, L. A., Teixeira, D. D. B., Barrón, V., \& Torrent, J. (2014). Magnetic susceptibility and diffuse reflectance spectroscopy to characterize the spatial variability of soil properties in a Brazilian Haplustalf. Geoderma, 219-220, 63-71. https://doi.org/10.1016/j.geoderma.2013.12.007

Montanari, R., Zambianco, E. C., Corrêa, A. R., Pellin, D. M. P., Carvalho, M. P., \& Dalchiavon, F. C. (2012). Atributos físicos de um Latossolo Vermelho correlacionados linear e espacialmente com a consorciação de guandu com milheto. Revista Ceres, 59(1), 125-135. https://doi.org/10.1590/S0034-737X2012000100018

Najafian, A., Dayani, M., Motaghian, H. R., \& Nadian, H. (2012). Geostatistical assessment of the spatial distribution of some chemical properties in calcareous soils. Journal of Integrative Agriculture, 11(10), 1729-1737. https://doi.org/10.1016/S2095-3119(12)60177-4

Novais, R. F., Venegas, V. H. A., Barros, N. F., Fontes, R. L. F., Cantarutti, R. B., \& Neves, J. C. L. (2007). Fertilidade do solo. Viçosa: Sociedade Brasileira de Ciência do Solo. p. 1017.

Parfitt, J. M. B., Timm, L. C., Pauletto, E. A., Sousa, R. O., Castilhos, D. D., Ávila, C. L. \& Reckziegel, N. L. (2009). Spatial variability of the chemical, physical, and biological properties in lowland cultivated with irrigated rice. Revista Brasileira de Ciência do Solo, 33, 819-830. https://doi.org/10.1590/S0100-06832009000400007

Polo, J. R. V., Garcia, D. B., \& Flores, J. C. M. (2010). Variabilidad espacial de propiedades físicas y químicas en suelos de la granja experimental de la Universidad Del Magdalena (Santa Marta, Colombia). Acta Agronómica, 59(4), 449-456.

Ponnamperuma, F. N. (1972). The chemistry of submerged soil. Advances in Agronomy, 24, 
29-96. https://doi.org/10.1016/S0065-2113(08)60633-1

Ranjbar, F., \& Jalali, M. (2016). The combination of geostatistics and geochemical simulation for the site-specific management of soil salinity and sodicity. Computers and Electronics in Agriculture, 121, 301-312. https://doi.org/10.1016/j.compag.2015.12.010

Reza, S. K., Baruah, U., \& Sarkar, D. (2016). Spatial variability of soil properties using geostatistical method: a case study of lower Brahmaputra plains, India. Arabian Journal of Geosciences, 9(6), 1-8. https://doi.org/10.1007/s12517-016-2474-y

Reza, S. K., Nayak, D. C., Mukhopadhyay, S., Chattopadhyay, T., \& Singh, S. K. (2017). Characterizing spatial variability of soil properties in alluvial soils of India using geostatistics and geographical information system. Archives of Agronomy and Soil Science, 63(11), 1489-1498. https://doi.org/10.1080/03650340.2017.1296134

Robertson, G. P. (1998). GS+: Geoestatistics for the environmental sciencies - GS+ User's Guide. Plainwell: Gamma Designing Software.

Rosemary, R., Vitharana, U. W. A., Indraratne, S. P., Weerasooriya, R., \& Mishra, U. (2017). Exploring the spatial variability of soil properties in an Alfisol soil catena. Catena, 150, 53-61. https://doi.org/10.1016/j.catena.2016.10.017

Rozane, D. E., Romualdo, L. M., Centurion, J. F., \& Barbosa, J. C. (2011). Dimensionamento do número de amostras para avaliação da fertilidade do solo. Semina: Ciências Agrárias, 32(1), 111-118. https://doi.org/10.5433/1679-0359.2011v32n1p111

Santos, F. A. S., Pierangeli, M. A. P., Silva, F. L., Serafim, M. E., \& Souza, C. A. (2015b). Atributos químicos, físicos e estoque de cálcio, magnésio, potássio e fósforo em solos de campos de murundus no Brasil. Acta Amazonica, 45(2), 101-110. https://doi.org/10.1590/1809-4392201402954

Santos, H. G., Jacomine, P. K. T., Anjos, L. H. C., Oliveira, V. A., Lumbreras, J. F., Coelho, M. R., Almeida, J. A., Araújo Filho, J. C.; Oliveira, J. B, \& Cunha, T. J. F. (2018). Sistema Brasileiro de Classificação de Solos. (5th ed.). Brasília: Embrapa. p. 356.

Santos, R. D., Santos, H. G., Ker, J. C., Anjos, L. H. C., \& Shimizu, S. H. (2015a). Manual de descrição e coleta de solo no campo. (7th ed.). Viçosa: Sociedade Brasileira de Ciência do Solo. p. 102.

Shukla, A. K., Behera, S. K., Lenka, N. K., Tiwari, P. K., Prakash, C., Malik, R. S., Sinha, N. K., Singh, V. K., Patra, A. K., \& Chaudhary, S. K. (2016). Spatial variability of soil micronutrients in the intensively cultivated trans-gangetic plains of India. Soil and Tillage Research, 163, 282-289. https://doi.org/10.1016/j.still.2016.07.004

Silva, F. A. S., \& Azevedo, C. A. V. (2016). The Assistant Software Version 7.7 and its use in the analyses of experimental data. African Journal of Agricultural Research, 11(39), 3733-3740. https://doi.org/10.5897/AJAR2016.11522

Sousa, D. M. G., \& Lobato, E. (2004). Cerrado: correção do solo e adubação. Brasília: 


\section{Macrothink}

Embrapa Informações Tecnológicas. p. 416.

Souza, M. E. (2017). Manganês suplementar na cultura do arroz irrigado. Master diss., Universidade Federal do Tocantins. p. 70.

Tesfahunegn, G. B., Tamene, L., \& Vlek, P. L. G. (2011). Catchment-scale spatial variability of soil properties and implications on site-specific soil management in northern Ethiopia. Soil and Tillage Research, 117, 124-139. https://doi.org/10.1016/j.still.2011.09.005

Thompson, S. K. (1992). Sampling. New York: John Wiley. p. 400.

Uyan, M. (2016). Determination of agricultural soil index using geostatistical analysis and GIS on land consolidation projects: A case study in Konya/Turkey. Computers and Electronics in Agriculture, 123, 402-409. https://doi.org/10.1016/j.compag.2016.03.019

Verma, U. S., Jatav, G. K., \& Bhagat, R. K. (2013). Evaluation of soil fertility status in Inceptisol of Malkharauda block in Janjgir district of Chhattisgarh. An Asian Journal of Soil Science, 8(1), 103-109.

Warrick, A. W., \& Nielsen, D. R. (1980). Spatial variability of soil physical properties in the field. In D. Hillel (Eds.), Applications of soil physics, (pp. 319-344). New York: Academic Press.

Xu, H., Cai, Z. C., Li, X. P., \& Tsuruta, H. (2000). Effect of antecedent soil water regime and rice straw application time on $\mathrm{CH} 4$ emission from rice cultivation. Soil Research, 38, 1-12. https://doi.org/10.1071/SR99026

Zimback, C. R. L. (2001). Análise espacial de atributos químicos de solos para fins de mapeamento da fertilidade. $\mathrm{PhD}$ diss., Universidade Estadual Paulista. p. 114.

\section{Copyright Disclaimer}

Copyright for this article is retained by the author(s), with first publication rights granted to the journal.

This is an open-access article distributed under the terms and conditions of the Creative Commons Attribution license (http://creativecommons.org/licenses/by/4.0/). 